\title{
PENGAMBILAN KEPUTUSAN PERAWAT SEBAGAI PEMECAHAN \\ MASALAH DALAM ASUHAN KEPERAWATAN
}

\author{
Novi Pratiwi \\ novipratiwi211@gmail.com
}

\begin{abstract}
Abstrak
Kemampuan membuat keputusan dalam pemecahan masalah etis menjadi salah satu persyaratan bagi perawat untuk menjalankan praktik keperawatan professional. Pengambilan keputusan perawat dilakukan pada semua tahap proses keperawatan. Sehingga seorang perawat harus mampu berpikir kritis dan berkomunikasi dengan baik sebagai suatu elemen penting dalam pengambilan keputusan klinis, sehingga terjadi pembelajaran berkelanjutan bagi pasien dan dapat meningkatkan tingkat kemandirian pasien. Pengambilan keputusan yang tepat dalam pemecahan masalah akan meningkatkan kemandirian klien dalam asuhannya serta membantu klien untuk menentukan pilihan bantuan yang tepat sesuai dengan kondisinya. Dan seorang perawat harus mampu mengambil keputusan dengan melibatkan pasien dan keluarga dalam asuhan keperawatannya.
\end{abstract}

Kata kunci : Perawat, pengambilan keputusan, pemecahan masalah

\section{Latar Belakang}

Kemampuan membuat keputusan masalah etis menjadi salah satu persyaratan bagi perawat untuk menjalankan praktik keperawatan professional. Pengambilan keputusan merupakan suatu pendekatan sistematis untuk menyelesaikan suatu masalah. Proses pengambilan keputusan merupakan komponen penting dalam proses keperawatan, sehingga dibutuhkan pengetahuan dan kemampuan perawat. Jika perawat memiliki keterbatasan pengetahuan dan kemampuan, maka hal tersebut dapat menghambat perawat dalam mengambil keputusan mengenai perawatan yang akan diberikan kepada klien yang akan berakibat fatal terhadap klien.

Proses pengambilan keputusan dalam praktik klinik keperawatan dipahami sebagai serangkaian keputusan yang dibuat oleh perawat dalam interaksinya dengan pasien mengenai jenis pengamatan yang akan dilakukan dalam situasi yang dialami klien (pengkajian keperawatan), perumusan diagnosa keperawatan, rencana tindakan keperawatan yang harus diambil, tindakan keperawatan yang akan diambil serta evaluasi. 
Pengambilan keputusan sangat penting keberadaannya dalam asuhan maupun dalam manajemen keperawatan. Pengambilan keputusan merupakan suatu proses yang mencakup semua penilaian kegiatan yang diperlukan guna membuktikan dan meperlihatkan pilihan terbaik dalam menyelesaiakan suatu masalah tertentu. Setiap keputusan adalah akibat dari sebuah proses dinamis yang dipengaruhi oleh banyak kekuatan. Pengambilan keputusan bukan merupakan prosedur yang tetap akan tetapi sebuah proses yang beruntun.

Seorang perawat harus mampu mengambil keputusan dengan melibatkan pasien dan keluarga dalam asuhan keperawatannya sehingga proses keperawatan yang diberikan kepada klien ini diarahkan sebagai proses refleksi baik bagi perawat ataupun klien. Keterlibatan pasien merupakan inti dari proses keperawatan, sehingga partisipasi pasien dalam proses keperawatan menjadi penting dalam penentuan kualitas dan efektifitas dalam pelayanan asuhan keperawatan. Membina hubungan ini didasarkan pada hubungan yang saling percaya, menghormati dan hubungan profesional dengan mengedepankan nilai etik dan disiplin profesi.

Pengambilan keputusan perawat dilakukan pada semua tahap proses keperawatan. Sehingga seorang perawat harus mampu berpikir kritis dan berkomunikasi dengan baik sebagai suatu elemen penting dalam pengambilan keputusan klinis, sehingga terjadi pembelajaran berkelanjutan bagi pasien dan dapat meningkatkan tingkat kemandirian pasien.

Ketepatan pengambilan keputusan akan di pengaruhi oleh kompetensi perawat, kemampuan berkomunikasi, lingkungan serta budaya. Penting bagi perawat untuk selalu meningkatkan kapasitas dirinya dalam pemberian asuhan keperawatan. Hal ini akan meningkatkan kepercayaan masyarakat terhadap perawat yang selanjutnya akan meningkatkan profesionalisme perawat. Pengambilan keputusan yang tepat akan meningkatkan kemandirian klien dalam asuhannya serta membantu klien untuk menentukan pilihan bantuan yang tepat sesuai dengan kondisinya. Klien yang mandiri akan menurunkan beban kerja perawat sehingga pelayanan keperawatan akan lebih efektif dan efisien dalam penggunaan sumber daya.

\section{Metode}

Metode yang dilakukan dalam penulisan ini adalah metode kepustakaan yaitu dengan melakukan peninjauan, mengumpulkan data-data dan menganalisisnya yang diperoleh dari buku, e-book, jurnal-jurnal terkini ataupun sumber informasi lainnya yang memuat informasi pembahasan tentang pengambilan keputusan perawat sebagai pemecahan masalah keperawatan. Pengolahan data dilakukan mulai dari menganalisis isi buku dan jurnal atau sumber informasi lainnya hingga kesimpulan dari penulis. 


\section{Hasil}

Permasalahan etika yang terjadi telah menimbulkan konflik antara perawat dengan pasien sehingga upaya untuk mencapai kesembuhan pasien menjadi tidak maksimal. Adanya permasalahan etik yang dilakukan perawat menandakan bahwa perawat tersebut belum memahami tentang pentingnya nilai etik dan moral serta nilai profesionalisme dalam keperawatan. Institusi Kesehatan Dunia tahun 2017 mengindentifikasi 98.000 pasien meninggal setiap tahun akibat pengambilan keputusan yang buruk dalam perawatan kesehatan.

Permasalahan etik yang terjadi dalam praktik keperawatan professional menuntut perawat berkewajiban dan bertanggung jawab menerapkan prinsip/asas etik dan kode etik serta mematuhi aspek legal keperawatan yang diatur dalam Kep.Menkes 148/2010 dan UU Kes 36/2009 dalam melaksanakan tugas perawat harus memperhatikan dan menghindari yang disebut dengan negligence (kealpaan), commision dan ommision.

Pemecahan masalah dan proses pengambilan keputusan membutuhkan pemikiran kritis dan analisis yang dapat ditingkatkan dalam praktek. Pengambilan keputusan merupakan upaya pencapaian tujuan dengan menggunakan proses yang sistematis dalam memilih alternatif. Tidak semua pengambilan keputusan dimulai dengan situasi masalah.

Untuk melakukan pengambilan keputusan yang tepat menggunakan suatu pendekatan yang sistematis terhadap hakekat suatu masalah dengan pengumpulan fakta-fakta dan data. Dalam menentukan alternatif yang matang untuk mengambil suatu tindakan yang tepat didasarkan pada kriteria tertentu atas dua atau lebih alternatif yang sesuai (George R. Terry, 2019). Pengambilan keputusan dalam penyelesaian masalah membutuhkan kemampuan yang mendasar bagi praktisi kesehatan, khususnya dalam asuhan keperawatan (Dolan, 2017). Pengambilan keputusan tidak hanya berpengaruh pada proses pengelolaan asuhan keperawatan, tetapi penting untuk meningkatkan kemampuan merencanakan perubahan.

Ada lima hal yang perlu diperhatikan dalam pengambilan keputusan, yaitu:

1. Dalam proses pengambilan keputusan tidak terjadi secara kebetulan.

2. Pengambilan keputusan tidak dilakukan secara sembrono tapi harus berdasarkan pada sistematika tertentu:

- Tersedianya sumber-sumber untuk melaksanakan keputusan yang akan diambil.

- Kualifikasi tenaga kerja yang tersedia

- Falsafah yang dianut organisasi.

- Situasi lingkungan internal dan eksternal yang akan mempengaruhi administrasi dan manajemen di dalam organisasi. 
3. Masalah harus diketahui dengan jelas.

4. Pemecahan masalah harus didasarkan pada fakta-fakta yang terkumpul dengan sistematis.

5. Keputusan yang baik adalah keputusan yang telah dipilih dari berbagai alternatif yang telah dianalisa secara matang.

\section{Pembahasan}

Perawat memiliki kewajiban etis untuk mendukung, meningkatkan dan membantu pengambilan keputusan, untuk mendukung hak klien pada informed consent, untuk memberikan informasi mengenai resiko yang akan datang ketika tindakan itu diberikan kepadanya dan untuk mengikuti jalan yang diambil klien. Pertimbangan etis yang meliputi tantangan dalam masalah dan dilema etis dapat diarahkan dengan metode proses asuhan keperawatan.

Kemajuan ilmu dan teknologi terutama di bidang biologi dan kedokteran telah menimbulkan berbagai permasalahan atau dilema etika kesehatan yang sebagian besar belum teratasi. Masalah bioetik semakin berkembang dengan munculnya berbagai sistem pelayanan kesehatan baru, seperti nursing care (perawat rumah) dan telenursing (perawatan jarak jauh). Contoh kasus masalah bioetik keperawatan seperti dalam keperawatan maternitas, yaitu masalah aborsi, kehamilan remaja, serta penanganan bayi berisiko tinggi dan dalam keperawatan gerontology, yaitu masalah penganiayaan lanjut usia, euthanasia, dan penanganan pasien HIV/AIDS.

Masalah etis atau dilema etis muncul ketika ketaatan terhadap prinsip menimbulkan penyebab konflik dalam bertindak. Dalam menghadapi masalah atau dilema etis, perawat wajib membantu pengambilan keputusan. Kemampuan membuat keputusan masalah etis merupakan salah satu persyaratan bagi perawat untuk menjalankan praktik keperawatan profesional. Setiap pengambilan keputusan tentunya tidak hanya berdasarkan pada pertimbangan ilmiah semata tetapi juga dengan mempertimbangkan etika. Hal terbaik sebelum diambil suatu keputusan sebaiknya didiskusikan terlebih dahulu antara klien dengan perawat atau petugas kesehatan yang akan melakukan suatu tindakan tertentu dengan mempertimbangkan berbagai informasi yang relevan.

Setiap masalah atau dilema etis berbeda cara pendekatannya, namun dalam situasi apapun perawat dapat menggunakan panduan berikut ini untuk pemrosesan dan pengambilan keputusan etis, yaitu:

a. Menunjukkan maksud baik 
Penting bagi perawat dan semua tim yang terlibat mengikuti diskusi etik dengan anggapan bahwa semua tim menemukan apa yang baik bagi tidakan yang akan diberikan kepada klien. Diskusi harus dimulai dengan etika baik dan kepercayaan pada semua anggota tim, jika tidak dimulai dengan saling percaya dan prinsip berbuat baik maka hasil yang diputuskan tidak akan memberikan kebaikan pada klien dan mencegah terjadinya kesalahan dan kejahatan pada klien dan keluarganya.

b. Mengidentifikasi semua orang penting

Sebelum pengambilan keputusan etis, perawat hendaknya mengingatkan bahwa semua orang/anggota tim ikut serta dalam proses pengambilan keputusan adalah penting. Tidak menilai seberapa besar porsi nilai yang diberikan oleh masing-masing anggota tim, prinsipnya bahwa keputusan yang diambil adalah keputusan bersama atau keputusan tim.

c. Mengumpulkan informasi yang relevan

Menggali atau mengumpulkan semua informasi sangatlah penting sebelum keputusan etis diambil. Informasi yang relevan meliputi data tentang pilihan klien, sistem keluarga, diagnosa dan prognosa medis, pertimbangan sosial dan dukungan lingkungan. Perawat atau tim perawat tidak dapat mengambil keputusan yang baik jika berdasarkan data-data atau informasi yang lemah. Oleh karena itu, perawat harus mampu mengumpulkan informasi yang paling relevan sebagai dasar pengambilan keputusan etis bagi klein.

d. Mengidentifikasi prinsip etis yang penting

Keputusan etis harus didasari dengan prinsip etis yang sesuai, walaupun prinsip etis yang umum dan universal tidak dapat menunjukkan pada perawat apa yang harus ia lakukan dalam situasi kritis. Tetapi prinsip etis tersebut tetap harus dijadikan standar pegangan bagi perawat untuk mengambil keputusan etis, karena dapat membantu menilai dalam situasi dilema tersebut. Sehingga dapat mencari solusi untuk mengesampingkan atau menghilangkan hal yang dapat menghalangi norma dan nilai keputusan etis akan menjadi lebih baik.

e. Mengusulkan tindakan alternatif

Perawat seringkali sulit mengatasi masalah etis yang dihadapi karena mereka hanya dapat melihat satu tindakan yang mungkin dapat diberikan kepada klien. Tanpa memberikan kebebasan untuk menentukan pilihan yang masuk akal yang dapat melindungi nilai kemanusiaan yang pada orang-orang yang terlibat.

f. Melakukan tindakan

Begitu keputusan etis telah diambil berdasarkan hasil diskusi tim yang dilakukan secara terbuka dengan melibatkan semua unsur yang terkait, maka perawat atau tim dapat 
mengimplementasikannya dalam bentuk tindakan keperawatan sesuai dengan standar asuhan keperawatan.

Dalam membuat keputusan etis, ada beberapa unsur yang mempengaruhi, yaitu nilai dan kepercayaan pribadi, kode etik keperawatan, konsep moral perawat, serta prinsip etis dan model kerangka keputusan etis. Untuk membuat keputusan yang etis, seseorang harus tergantung pada pemikiran yang rasional dan bukan emosional.

Menurut Kozier and Erb (1989) kerangka pemecahan masalah atau dilema etis sebagai berikut:

1) Mengembangkan data dasar

2) Mengidentifikasi konflik yang terjadi berdasarkan situasi tersebut

3) Membuat tindakan alternatif tentang rangkaian tindakan yang direncanakan dan mempertimbangkan hasil akhir atau konsekuensi tindakan tersebut

4) Menentukan siapa yang terlibat dalam masalah tersebut dan siapa pengambil keputusan yang tepat

5) Mendefinisikan kewajiban perawat

6) Membuat keputusan

Contoh kasus, Ibu A usia 65 tahun, dirawat di RS, dengan laserasi dan fraktur multipel akibat kecelakaan kendaraan bermotor. Suaminya juga ada dalam kecelakaan tersebut tetapi ia meninggal di RS yang sama. Pada saat kecelakaan terjadi, ibu A yang mengendarai mobil. Saat di RS, ibu A terus menerus menanyakan suaminya kepada perawat yang merawatnya. Dokter bedah sudah mengatakan kepada perawat untuk tidak memberitahukan ibu A tentang kematian suaminya. Perawat tersebut tidak mengetahui alasan untuk tidak memberitahukan keadaan ini kepada klien dan ia bertanya kepada kepala ruangan. Kepala ruangan mengatakan untuk tidak memberitahu klien tentang kematian suaminya.

Penerapan pemecahan masalah atau dilema etis dari kasus tersebut yaitu:

- Mengembangkan data dasar

- Orang yang terlibat: klien, suami klien, dokter bedah, kepala ruang rawat dan perawat primer.

- Tindakan yang diusulkan: tidak memberi tahu klien tentang suaminya.

- Maksud dari tindakan tersebut: mungkin untuk mencegah ibu A dari trauma psikologis.

- Konsekensi tindakan yang diusulkan: bila informasi tidak diberitahu, klien akan terus cemas, marah dan mungkin akan menolak tindakan yang akan dilakukan dan akibatnya proses penyembuhan akan terganggu. 
- Identifikasi konflik akibat situasi tersebut

Konflik yang terjadi adalah pada perawat primer yaitu:

- Ingin jujur pada klien tetapi tidak setia pada dokter bedah dan kepala ruang rawat.

- Ingin setia pada dokter bedah dan kepala ruang rawat tetapi tidak jujur pada klien.

- Konflik tentang efek yang mungkin timbul pada klien jika klien diberitahu atau tidak diberitahu.

- Pikirkan tindakan alternatif terhadap tindakan yang diusulkan dan pertimbangkan konsekuensi tindakan alternatif tersebut.

Mengikuti anjuran dokter bedah dan kepala ruang rawat, konsekuensi tindakan ini yaitu:

- Resiko sebagai perawat yang tidak asertif

- Mengingkari nilai pribadi untuk menyatakan hal yang sebenarnya pada klien

- Mungkin menguntungkan pada kesehatan ibu A

- Mungkin membuat kesehatan ibu A bertambah buruk

Mendiskusikan hal tersebut lebih lanjut dengan dokter bedah dan kepala ruang rawat dengan menegaskan hak ibu A, untuk mendapatkan informasi dan penghargaan atas otonominya. Konsekuensi tindakan ini antara lain:

- Dokter bedah mungkin akan menyadari hak ibu A, tentang pemberian informasi dan akibatnya memberi tahu ibu A, tentang kematian suaminya

- Dokter bedah mungkin akan tetap pada pendapatnya untuk tidak memberi tahu ibu A, tentang kematian suaminya.

- Menetapkan siapa pembuat keputusan yang tepat.

Dalam hal ini perlu dipikirkan:

- Siapa yang sebaiknya terlibat dalam membuat keputusan dan mengapa?

- Untuk siapa saja keputusan itu dibuat?

- Apa kriteria untuk menetapkan siapa pembuat keputusan (sosial, ekonomi, fisiologi, psikologik, peraturan/hukum)

- Sejauh mana persetujuan klien dibutuhkan?

- Apa prinsip moral yang ditekankan atau diabaikan oleh tindakan yang diusulkan?

Dalam contoh di atas, dokter bedah yakin bahwa pembuat keputusan adalah dirinya dan kepala ruang setuju. Namun, kriteria siapa yang seharusnya pembuat keputusan tidak jelas. Bila kriteria sudah disebutkan mungkin konflik tentang efek memberi informasi atau tidak memberi informasi tentang kesehatan ibu A, sudah dapat diselesaikan.

- Mendefinisikan kewajiban perawat 
Untuk membantu memutuskan, perawat perlu membuat daftar kewajiban perawat yang harus diperhatikan, contoh kewajiban tersebut adalah:

- Meningkatkan kesejahteraan klien

- Membuat keseimbangan antara kebutuhan klien tentang otonomi dan tanggung jawab keluarga tentang kesehatan klien

- Melaksanakan peraturan RS

- Melindungi standar keperawatan

- Membuat keputusan

Dalam suatu masalah atau dilema etis, tidak ada jawaban yang benar atau salah. Mengatasi hal ini, tim kesehatan perlu mempertimbangkan pendekatan yang paling menguntungkan / paling tepat untuk klien. Jika keputusan sudah ditetapkan, secara konsisten keputusan tersebut dilaksanakan dan apapun yang diputuskan untuk kasus tersebut, itulah tindakan etis dalam keadaan tersebut.

\section{Penutup}

Kesimpulan dan Saran

Pengambilan keputusan merupakan suatu proses yang mencakup semua penilaian kegiatan yang diperlukan guna membuktikan dan meperlihatkan pilihan terbaik dalam menyelesaiakan suatu masalah tertentu. Kemampuan membuat keputusan masalah etis menjadi salah satu persyaratan bagi perawat untuk menjalankan praktik keperawatan professional. Untuk melakukan pengambilan keputusan yang tepat menggunakan suatu pendekatan yang sistematis terhadap hakekat suatu masalah dengan pengumpulan fakta-fakta dan data.

Setiap pengambilan keputusan tidak hanya berdasarkan pada pertimbangan ilmiah tetapi juga mempertimbangkan etika. Maka, sebelum diambil suatu keputusan sebaiknya didiskusikan terlebih dahulu antara klien dengan perawat atau petugas kesehatan yang akan melakukan suatu tindakan tertentu dengan mempertimbangkan berbagai informasi yang relevan.

\section{Daftar Pustaka}

Ardiyani, V. M. (2018). Analisis peran perawat terhadap ketepatan penentuan prioritas i, ii, \& iii pada ruang triage di IGD RS dr. Saiful Anwar Malang. Jurnal Ners LENTERA, 6(2), 103-113.

Budiono, S. B. P. (2015). Konsep dasar keperawatan. Jakarta: Bumi Medika. 
Deniati, K., Anugrahwati, R. \& Suminarti, T. (2018). Pengaruh berfikir kritis terhadap kemampuan perawat pelaksana dalam melakukan asuhan keperawatan di RS Hermina Bekasi tahun 2016. Jurnal Kesehatan Holistik, 12(1), 21-25.

Dermawan, D. (2012). Proses keperawatan: Penerapan konsep \& kerangka kerja. Yogyakarta: Gosyen.

Haryono, R. (2013). Etika keperawatan dengan pendekatan praktis. Yogyakarta: Gosyen Publishing

Hasyim, dkk. (2012). Etika keperawatan. Yogyakarta: Bangkit

Pashar, I. \& Dwiantoro, L. (2020). Pengaruh empowerment terhadap pengambilan keputusan perawat: Kajian literature review. Journal of Holistic Nursing Science, 7(2), 124-132.

Purwati, E. I. I., Nuryadi, \& Herawati, Y. T. (2017). Pengambilan keputusan dalam pelaksanaan rujukan puskesmas sebagai fasilitas kesehatan tingkat pertama. e-Jurnal Pustaka Kesehatan, 5(2), 231-238.

Rahayu, C. D. \& Mulyani, S. (2020). Pengambilan keputusan klinis perawat. Jurnal Ilmu Kesehatan, 10(1), 1-11.

Simamora, R. H. (2019). Menjadi perawat yang: CIH'HUY. Surakarta: Kekata Publisher.

Simamora, R. H. (2005). Hubungan Persepsi Perawat Pelaksana Terhadap Penerapan Fungsi Pengorganisasian Yang Dilakukan Oleh Kepala Ruangan Dengan Kinerjanya Diruang Rawat Inap RSUD Koja Jakarta Utara (Doctoral dissertation, Tesis FIK UI, Tidak dipublikasikan).

Sudono, B., Setya, D., \& Atiningtyas, R. (2017). Gambaran kemampuan berpikir kritis perawat primer dalam pelaksanaan asuhan keperawatan di RS Islam Surakarta. Jurnal Ilmu Keperawatan Indonesia, 10(1), 79-106.

Utami, N. W., dkk. (2016). Etika keperawatan dan keperawatan profesional. Jakarta: Pusdik SDM Kesehatan. 